\title{
Screening of Antibacterial Properties for Some Iraqi Plants Against Salmonella typhimurium
}

Salma N. Malik*

Huda J. Mohammed**

Janet Arshak Misak***

*Institute of Medical Technology - Baghdad.

** College of Pharmacy - Baghdad University.

*** Institute of Medical Technology - Mansour.

Accepted on 21/6/2011

\section{Summary}

This study was include the investigation of the antibacterial activity of ethanolic extract for (12) type of Iraqi plant leaves (Allium porrum L, Apium graveolens Mill., Cassia angustifollia Vahl., Lawsonia inermis L., Lepidium sativum L., Malva sylvestris L., Monthapiperita L., Ocimmum bassillicum L., Pettroselinum crispum Mill., Raphanus sativus L., Sponacia oleraceal. and Trigonella foenum L.). In different concentrations $(20,40,60,80,100) \mathrm{mg} / \mathrm{ml}$ against Salmonella typhimurium in vitro using agar well diffusion method. All ethanolic extract of leaves showed a high activity against this bacterium except of Cassia angustifollia Vahl. as compared with the other extracts. The ethanolic extract of leaves of Petroselinum crispum Mill was showed the best activity with inhibition zone of twenty three $\mathrm{mm}$ in the concentration (100) $\mathrm{mg} / \mathrm{ml}$. This results confirm the antibacterial activity of these plants, and leaf components which are responsible for this action have to be isolated for using as therapeutic agents.

Conclusion: The present investigation together with previous studies provide support to the anti-Salmonella typhimurium properties of studied plant leaves. It can used as antibacterial supplement towards the development of the new chemotherapy. Additional in vivo studies and clinical trails would be needed to justify and further evaluate the potential of these plants as anti-Salmonella typhimurium agent in treatment of infectious diseases caused by this bacteria.

Keywords: Antibacterial activity, Iraqi plant leaves, Salmonella typhimurium E-mail: h.mastermaster@yahoo.com 
The Iraqi J. Vet. Med. 35 ( 2 ): 28 - 35; 2011

فحص الصفات الضد بكتيرية لعدد من النباتات العر اقية ضد جرثومة

Solmonella typhimurium

المعهد الطبي ارشاك ميساك / التقي / المنصور

\author{
جامعة بغداد / كلية الصيدلة
}

المعهد الطبي التقني - بغداد الله مالك

تضمنت هذه الدراسة تقصي الفعالية الضد بكتيرية للمستخلص الاثيلي لـ (12)

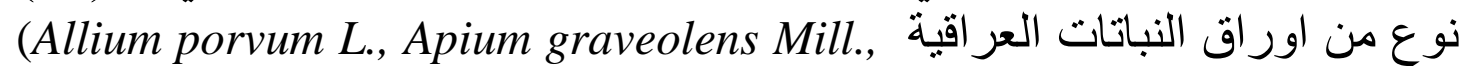
Cassia angustifollia Vahl., Lawsonia inermis L., Lepidium sativum L., Malva sylvestris L., Monthapiperita L., Ocimmum bassillicum L., Pettroselinum crispum Mill., Raphanus sativus L., Sponacia oleracea L., and Trigonella foenum L.

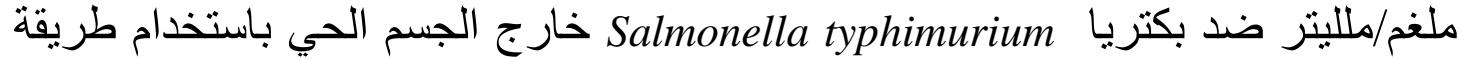

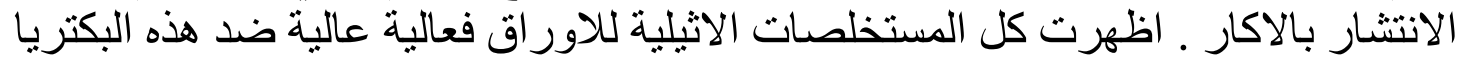

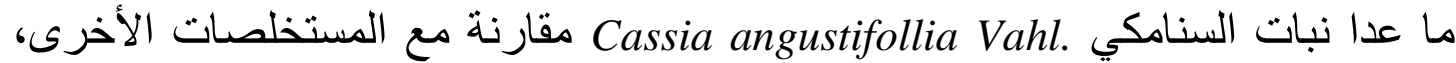

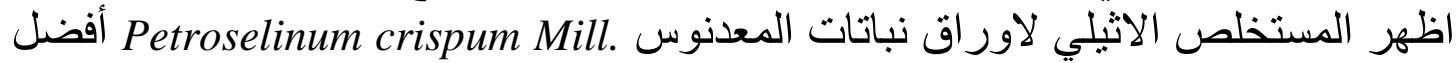

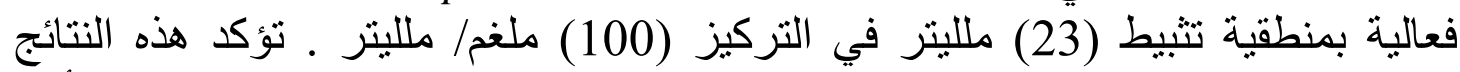

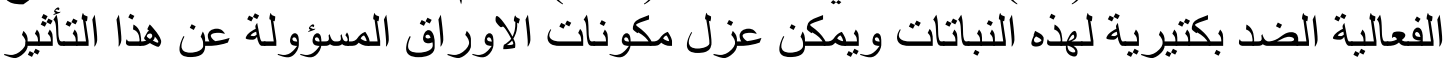

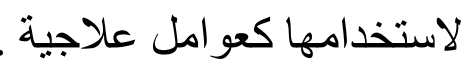

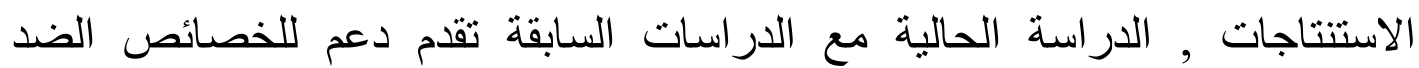

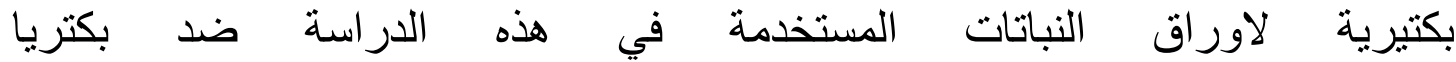

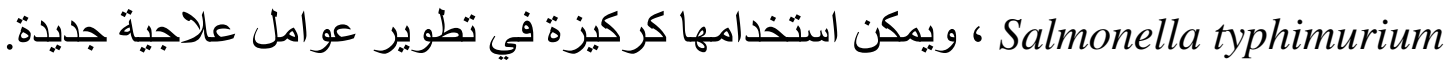

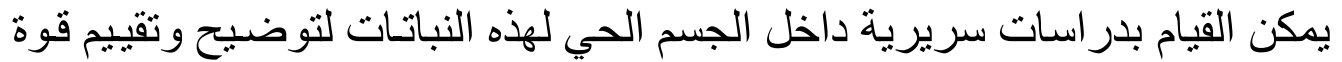
هذه النباتات كعو امل ضد بكتيرية في علاج الاخماج المسببة من قبل هذه البكتريا.

\section{Introduction}

According to the reports of many researches, antibacterial resistance is a worldwide growing-problem (1). The problem of microbial resistance is growing and the outlook for the antimicrobial drugs in the future is still uncertain. Therefore, actions must be taken to reduce the problem, for example, to control the use of antibiotic, develop research to better understand the genetic mechanisms of resistance and to continue studies to develop new drugs, either synthetic or natural. The ultimate goal is to offer appropriate and efficient antimicrobial drugs to the patient (2, 3 and 4$)$.

Many higher plants accumulate extractable organic substances in quantities sufficient to be economically useful as pharmaceuticals antibiotics. Species of higher plants are much less surveyed for antibacterial activity (2 and 5). The use of herbs as complementary in the last 20-25 years, and according to world health organization (WHO) traditional medicines are relied upon by $65-80 \%$ of the words population 
of their primary care needs (6). Antibacterial active principles isolated from higher plants is appears to be one of the important alternative approaches to contain antibiotic resistance and the management of disease. It is believed that plants based drugs cause less or no side effect when compared with synthetic antibiotics (2 and 7). Salmonella typhimurium is a pathogenic Gram-negative bacteria predominately found in the intestinal lumen (8). This bacterium is a serious public health problem in developing countries and represents a constant concern for the food industry (9). It causes enteric fever and invade intestinal mucosa and multiply in macrophages in intestinal lymph follicles, enter mesenteric lymph gland to blood and dissemination. The clinical features of infection include insidious onset malaise, anorexia maligns and headache (10 and 11). Shan et al examined 46 medicinal plant extract by agar well diffusion method against 5 foodborn bacteria and found that Gram-positive bacteria were generally more sensitive to the extract from Gram-negative bacteria(12).

In the present research, inhibitory effects of 12 Iraqi green leaves were investigated against Salmonella typhimurium.

\section{Materials and methods}

Plant material: Fresh leaf material of 12 species of plants were collected from Baghdad city, Iraq. Table (1). The leaves were washed thoroughly several times with running tap water and once with sterile distilled water. The leaf material was air-dried on a sterile blotter under shade (7). A voucher specimen of all plants has been deposited in the Department of Pharmacognosy, College of Pharmacy, University of Baghdad, Iraq.

Preparation of extract: The leaves were extracted by dissolving in ethanol-distilled water and then collecting the supernatants. This process repeated three times. Finally the ethanolic extracts were incubated at room temperature for 48 hours. After dryness al extracts were dissolved in $5 \mathrm{ml}$ of DMSO (dimethyl sulfoxide solvent) to get the concentration 20, 40, 60, 80, 100mg/ml. (13).

Preparation of bacterial inoculums: Bacterial suspension of Salmonella typhimurium was prepared according to McFarland nephdometer standard. A 24 hour old culture was used for preparation of bacterial suspension. The isolated colony was made in a sterile isotonic solution of sodium chloride $(0.9 \%)$ and the turbidity was adjusted such that it contained approximately $1.5 \times 10^{8}$ cells $/ \mathrm{ml}$. It was obtained by adjusting the optical density of the bacterial suspension to that of a solution of 0.05 of $1.175 \%$ of barium chloride and $9.95 \mathrm{ml}$ of $1 \%$ sulphuric acid (14).

Antibacterial activity: The antibacterial assay was performed by the agar well diffusion method. The medium (Muller Hinton) was prepared by dissolving all the ingredients in distilled water and subjected to sterilization in an autoclave at $121 \mathrm{C}^{\mathrm{o}}$ for 15 minutes. The Petriplates 
The Iraqi J. Vet. Med. 35 ( 2 ): 28 - 35; 2011

were sterilized in hot air oven at $160 \mathrm{C}^{0}$ for 1.5 hours. $30 \mathrm{ml}$ of sterile Muller Hinton agar was inoculated with microorganism (about $0.4 \mathrm{ml}$ according to McFarland standard). Pores were made on the medium by using a sterile borer and $0.1 \mathrm{ml}$ of each extract was added to the respective pore. The Petriplates inoculated with micro-organism, containing extracts were kept in refrigerator at $4 \mathrm{C}^{\circ}$ for 1 hour to facilitate the diffusion of extracts into the medium. After diffusion, the Petriplates were incubated at $37 \mathrm{C}^{\mathrm{o}}$ for 24 hours in an incubator and zone of inhibition was observed and measured using a scale (15).

Table (1) : List of species of tested plants for antibacterial activity [2].

\begin{tabular}{|l|l|}
\hline Name of the plant & Family \\
\hline Allium porrum $L$. & Alliaceae \\
\hline Apium graveolens Mill. & Apiaceae \\
\hline Cassia angustifollia Vahl. & Leguminosae \\
\hline Lawsoing inermis $L$. & Lythraceae \\
\hline Lepidium sativum $L$. & Crucifera \\
\hline Malva sylvestris $L$. & Malvaceae \\
\hline Mentha piperita $L$. & Lamiaceae \\
\hline Ocimmum bassillicum $L$. & Lamiaceae \\
\hline Petroselinum bassillicum $L$. & Umbelliferae \\
\hline Raphanus sativus $L$. & Brassicaceae \\
\hline Spanacia aleracea $L$. & Chenopodiaceae \\
\hline Trigonella foenum $L$. & Papilionaceae \\
\hline
\end{tabular}

\section{Results and Discussion}

Recently, much attention has been directed towards plant extracts and biological active compounds isolated from popular plant species (16). The use of medicinal plants plays a vital role in developing countries and these plants may offer a new source of antibacterial agents like flavorides, phenolic, polyphenols, tannins, terpenoides and sequitorpenes with significant activity against infective microorganisms (17, 18 and 19). The anti-Salmonella typhimurium activity of ethanolic extracts for 12 type of Iraqi plant leaves are presented in Fig. (1 and 2) and table 2.

The results shown that all the ethanolic extracts (except one) prouduced zones of inhibition in the agar well diffusion method. We found that Peterselinum crispum was the most active tested plant against Salmonella typhimurium with inhibition zone $23 \mathrm{~mm}$ in the concentration $100 \mathrm{mg} / \mathrm{ml}$, followed by Trigonella foenum L. and Malva sylvestris L.with inhibition zones $21,20 \mathrm{~mm}$ in the same concentration. The antibacterial effect was demonstrated by previous workers (12, 16, 20 and 21). The other plants like Allium porrum, Apium graveolens, Lawsonia inermis L., Menthe piperita, Ocimum basillicum, , Lepidium sativum Raphanus sativus, Spanacia aleracea, have a good anti-Salmonella typhimurium activity in all concentration. To some extent, these results were similar to 
those of previous studies (12, 22, 23, 24, 25 and 26). The organic solvent extract exhibit greater antibacterial activity because the antibacterial principles were either polar or not polar and they were extracted only through organic solvent medium. Organic solvent extraction was suitable to verify the antibacterial properties of medicinal plants and they supported by many investigators (27, 28 and 29). In the other hand the ethanolic extract of Cassia angustifollia leaves was the least effect as compared with the other extracts. This suggests may be some particular anti-Salmonella substances in these extracts, which are lack in case Cassia angustifollia plant (12). The method of extraction (the ethanolic extract possess antibacterial activity than methanolic extract), the plant material and it's form (water crushed or finely powdered) affected their antibacterial activity, also the filtration of extract which might have led to remove of the antibacterial activity components $(3,30$ and 31$)$. The obtained results may provide a support to use these plants in traditional medicine.

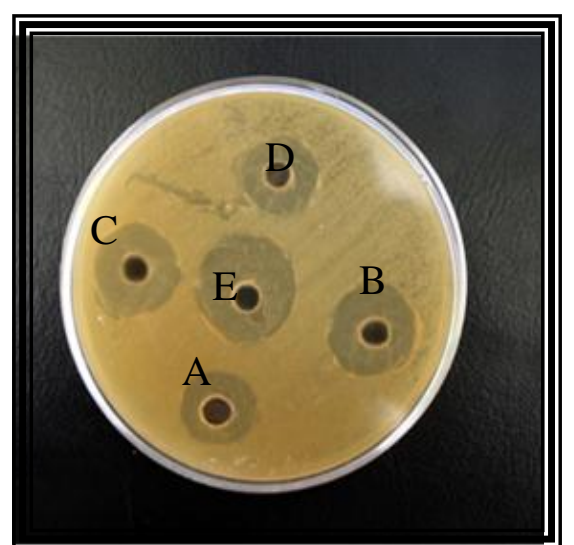

Fig.(1):The antibacterial activity of Petroselinum crispum leaves against Salmonella typhimurium

A : $20 \mathrm{mg} / \mathrm{ml}$ of ethanolic green leaves extracts

B : $40 \mathrm{mg} / \mathrm{ml}$ of ethanolic green leaves extracts

C : $60 \mathrm{mg} / \mathrm{ml}$ of ethanolic green leaves extracts

D : $80 \mathrm{mg} / \mathrm{ml}$ of ethanolic green leaves extracts

E : $100 \mathrm{mg} / \mathrm{ml}$ of ethanolic green leaves extracts

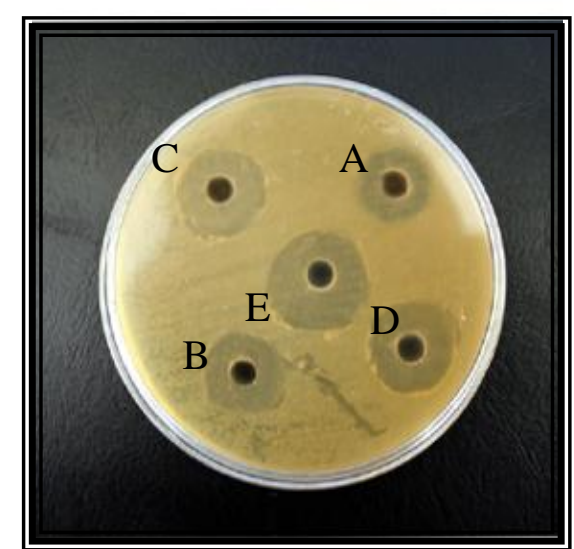

Fig. (2) : The antibacterial activity of Trigonella foenum leaves against Salmonella typhimurium 
The Iraqi J. Vet. Med. 35 ( 2 ): 28 - 35; 2011

Table 2 : Results of Screening of 12 ethanolic green leaves extracts against Salmonella typhimurium

\begin{tabular}{|c|c|c|}
\hline Name of plants & Concentration (mg/ml) & Zone of inhibition(mm) \\
\hline \multirow{5}{*}{ Petroselinum crispum Mill. } & 20 & 17 \\
\hline & 40 & 18 \\
\hline & 60 & 18 \\
\hline & 80 & 21 \\
\hline & 100 & 23 \\
\hline \multirow{5}{*}{ Trigonella foenum $L$. } & 20 & 7 \\
\hline & 40 & 12 \\
\hline & 60 & 15 \\
\hline & 80 & 19 \\
\hline & 100 & 21 \\
\hline \multirow{5}{*}{ Malva sylvestris $L$. } & 20 & $\overline{6}$ \\
\hline & 40 & 8 \\
\hline & 60 & 10 \\
\hline & 80 & 17 \\
\hline & 100 & 20 \\
\hline \multirow{5}{*}{ Allium porrum $L$. } & 20 & 12 \\
\hline & 40 & 13 \\
\hline & 60 & 15 \\
\hline & 80 & 15 \\
\hline & 100 & 18 \\
\hline \multirow{5}{*}{ Apium graveolens Mill. } & 20 & - \\
\hline & 40 & 6 \\
\hline & 60 & 10 \\
\hline & 80 & 13 \\
\hline & 100 & 18 \\
\hline \multirow{5}{*}{ Lawsania inermis $L$. } & 20 & $\overline{7}$ \\
\hline & 40 & 7 \\
\hline & 60 & 9 \\
\hline & 80 & 13 \\
\hline & 100 & 17 \\
\hline \multirow{5}{*}{ Menthe pipertita $L$. } & $\overline{20}$ & 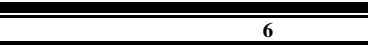 \\
\hline & 40 & 8 \\
\hline & 60 & 11 \\
\hline & 80 & 14 \\
\hline & 100 & 15 \\
\hline \multirow{5}{*}{ Ocimmum bassillicum $L$. } & 20 & 8 \\
\hline & 40 & 10 \\
\hline & 60 & 11 \\
\hline & 80 & 14 \\
\hline & 100 & 14 \\
\hline \multirow{5}{*}{ Lepidium sativum $L$. } & $\overline{20}$ & - \\
\hline & 40 & 8 \\
\hline & 60 & 8 \\
\hline & 80 & 11 \\
\hline & 100 & 12 \\
\hline \multirow{5}{*}{ Rophanus sativus $L$. } & 20 & 7 \\
\hline & 40 & 8 \\
\hline & 60 & 10 \\
\hline & 80 & 11 \\
\hline & 100 & 11 \\
\hline \multirow{5}{*}{ Spanacia oleracea $L$. } & $\overline{20}$ & $\overline{6}$ \\
\hline & 40 & 8 \\
\hline & 60 & 8 \\
\hline & 80 & 9 \\
\hline & 100 & 11 \\
\hline \multirow{5}{*}{ Cassia angustifollia Vahi. } & $\overline{20}$ & - \\
\hline & 40 & 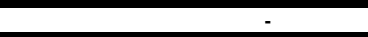 \\
\hline & 60 & - \\
\hline & 80 & \\
\hline & 100 & 4 \\
\hline
\end{tabular}




\section{References}

1. Bonjar GH (2004). Screeing for antibacterial properties some lranian plants against two strains of Escherichia coli, Asain. J Plant Sci.3(3): 310-314.

2. Satish S Raghavendra MP and Raveesha KAS (2008). Evaluation of the antibacterial potential of some plants against human pathogenic bacteria. Adva Bio Res.2 (3) : 44-48.

3. Werner F Okemo $\mathrm{P}$ and Ansorg R (1999). Antibacterial activity of East African medicinal plant. J Ethnophamacol.60: 79-84.

4. Samy RP and Ignacimuthu S (2000). Antibacterial activity of some folklore medicinal plants used by tribals in Western Ghats of India. J Ethnopharmacol.69: 63-71.

5. Shariff N Sudarshana MS Vmesha S and Hariprasad P (2006). Antimicrobial activity of Rauvolfia tetraphylla and Physalis minima leaf and callus extracts. Afr J Biotechnal.5: 946-950.

6. Kaur GH Arora DS (2009). Antibacterial and phytochemical screening of anethum groveolens, Foeniculum vulgare and Trachy spermum ammi. Res. Article.

7. Suffredini B Sada HS Goncalves A Rei AO Gales AC Varella AD and Younges RN (2004). screening of antimicrobial extracts from plants native to the Brazillian Amazon Rainforest and Atlantic Forest. Braz J Med Biol Res.37; 379-384.

8. Slauch M and James R. (2007). Acetylation (O- Factors 5) affects the structural and immunological. Infection and Immunity. Am Soci Micro.63(2) : 437-441.

9. Mastroeni P (2002). Immunity of Systemic Salmonella Infections Curr Med.2 : 393-406.

10. Miao M and Edward D (2007). "Salmonella typhimurium Leucine-rich repeat" J Mol Micro.34(4) : 850-864.

11. Everest O and Paul G (2007).Evaluation of Salmonella typhimurium mutants in a model of experimental gastroenteritis. Am So Micro.67(6) : 2815-2821.

12. Shan B Cai Y Brook J and Cork H (2007). In vitro antibacterial activity of dietary spice and medicinal herb extracts. Int J Food. Micro.117:112-119.

13. Okemo PO Mwatha WE Chhabra SC and Fabrv W (2003). The kill kinetics of Azadirachta indica against staphylococcus aureus, Escherichia coli, Psedomonas aeruginosa and Condida albicans. Afr J Scl Tech.2: 1.

14. Roopashree TS Dang R Rani RH and Narendra C (2008). Antibacterial activity of antisporiatic herbs: Cassia tora, Momordica charantia and Calendula officinalis. Int J App Res.1 (3) : 20-28.

15. Parekh $\mathbf{J}$ and Chanda $S$ (2007). In vitro screening of antibacterial activity of aqueous and alcoholic extracts of various Indian plant species against selected pathogens from Enterobacteriaceae. Afr J Res.1 (6) : 92-99.

16. Girish V and Satish S (2008). Antibacterial activity of important medicinal plants on human pathogenic bacteria- a comparative analysis. App Scl J.5(3) : 267-271..

17. Mingarro D Acero N Linares F Pozuclo J M Galo A and Mera Vicenta JA (2003). Biological activity of extracts from Catalpa bignonioides walt (Bignoniaceace). J Ethanopharmacol.87:163-167.

18. Evons CE Banso A and Samael OA (2002). Efficacy of some mupe medicinal plants against Salmonella typhi: an in vitro study. J Elhnopharmacol..80 : 2124. 
The Iraqi J. Vet. Med. 35 ( 2 ): 28 - 35; 2011

19. Ravikumar HS Makari HK. and Gurumurthy H (2007). In vitro Antimicrobial activity of ethanol extract of theretia peruviana. EJEAFChe.6 (9) : 2318-2322.

20. Akroms S Satta D and Lalaoul K(2009).Antimicrobial antioxidant. cytotoxic cctivities and phytochemical screening of some Algerian plants. Euro J Scl Res.31 (2) 289-295.

21. Arora DS and Kaur GJ (2007). Antibacterial activity of some Indian medicinal plant J NMat Med.61 : 313-317.

22. AL-Howiring TA AL-Sohaibani MO EL-TahirKH and Rafatullah S (2003). Preliminary evaluation of anti-flammantary and anti-hepatotoxic activities of ' Parsley' Petroselinum crispum in rats. J Natural Remedies.3 (1) : 54-62.

23. Negi PS and Jayaprakasha GK(2003).Antioxidant and antibacterial activities of punica granatum peel extracts. J Food Sci.68: 1473-1477.

24. Kaur GJ and Arora DS (2010). Bioactive potential of Anethum graveolens Foeniculum vulgare and Trachyspermum ammi belonging to the family Umbelliferae-Current status., Med Plant Res.4(2): 49-52.

25. Adebolu TT and Oladimeji SA (2005). Antimicrobial activity of leaf extract of Ocimum gratissimum on selected diarrhoea causing bacteria in Southwestern Nigeria. Afr J Bio Tech.4(4): 682-684.

26. Ranil I Akhund S and Abro H (2008). Antimicrobial potentail of seed extract of Raphanas sativus. J Bot.40(4): 1793-1798.

27. Patil HS Makari HK and Gurumurthy H (2007). In vitro Antimicrobial activity of ethanol extract of Thevetia peruviange. Elec $\mathrm{J}$ Enviro Agri and FoodChem.6(9):2318-2322.

28. Britto JS (2001). Comparative antibacterial activity study of Solanum incanum L. J Swamy Bot Club.18: $81-82$.

29. Krishna KT Ranjini CE and Sasidharan VK (1997). Antibacterial and antifungal activity of secondary metabolities from some medical and other common plant spacies. J Life Sci.2 : 14-19.

30. Natarajan E Senthilkumar S Xavier FT and Kalaiselvy V (2003). Antibacterial activities of leaf extracts of Alangium salviifolium. J Trop Med. Plants.4: 9-13.

31. Bazzaz BS and BS and Haririzadeh G (2003). Screening of Irania plants for antimicrobial activity. Bharm Biol.41 : 73-585. 